\title{
How a Smart Technology Imposed by an Organization Can Arouse Ambivalent Psychological Empowerment: An Approach Leveraging the Theory of Social Representations
}

\author{
Virginie Schweitzer \\ University of Haute-Alsace
}

The present research applies the conceptual background of psychological empowerment to explore customer cognitions regarding smart technologies, particularly when deployment is imposed by an organization, as well as their impact on the use of the device. We conducted an analysis of the structure of social representations regarding smart meters in France, demonstrating the existence of three patterns of ambivalent psychological empowerment when referring to the dimensions of the construct: forced autonomy (self-determination dimension), symbolic ambivalence of modernity (meaning), and ambivalence of artificial intelligence (impact dimension). Furthermore, the specific ambivalent pattern of the impact dimension of psychological empowerment, relating to artificial intelligence and privacy, seems to negatively influence smart meter use. These results provide important implications for scholars and managers of organizations alike.

Keywords: psychological empowerment, smart technologies, customer participation, forced deployment, social representations

\section{INTRODUCTION}

In the last decade, organizations' initiatives to raise customers' participation in the achievement of collective objectives have proliferated, as illustrated by Hewlett Packard's recycling program, which encourages customers to drop off their electronic waste through "free drop-off options" created for this specific purpose. Recently, these initiatives requiring customers to participate in new tasks have often implied the forced deployment of smart devices, also called "the Internet of Things (IoT)", which have the capacity to collect, exchange data and communicate with other objects and services over the internet to accomplish objectives (Whitmore et al., 2015); for example, energy organizations have attempted to raise customers' monitoring of their energy consumption through the installment of smart meters in private homes, providing detailed information on individual electric consumption. The high cost of smart technologies meant to be balanced out by customer use of the devices outlines the importance for organizations to provide the conditions conducive to effective customer participation. In France, in the context of the European Directive of July 13th, 2009 on Energy Transition, the public electricity distributor Enedis introduced the nationwide distribution of "Linky" smart meters from 2015 to 2021. However, the deployment faced mitigated reactions, as shown by the emergence of "anti-Linky" subversive groups and controversies disseminated through the media. Rejection of the forced-deployed device mainly related to breach of freedom of choice and data dissemination threats. The observation of these tensions motivated 
the present research, which aims to explore how an organization can facilitate customer participation in new tasks, specifically when these tasks require the use of smart technologies. Smart meter deployment in France is the research object in the present work.

A study of the existing literature in the fields of information systems and self-service technologies permitted us to first review the antecedents of technology acceptance (Davis et al., 1989; Parasuraman \& Colby, 2015; Venkatesh \& Bala, 2008; Venkatesh, Thong \& Xu, 2012) and motivations to use self-service technologies (Blut, Wang et Schoefer, 2016; Dabholkar et al., 2003; Ding et al., 2007; Meuter et al, 2003). Furthermore, an overview of the literature in the specific field of energy economics permitted us to review customers' motivations to use smart meters' information feedback (Abrahamse et al., 2007; Buchanan et al., 2015; Darby, 2006; Fischer, 2008; Hargreaves, 2010; Strengers, 2013; Torriti et al., 2010). However, two main gaps were identified. First, no research has addressed the question of individuals' psychological empowerment (PE), extensively examined in management literature and defined as an "increased intrinsic task motivation manifested in a set of four cognitions (competence, meaning, impact and selfdetermination) reflecting an individual's orientation to his or her work role" (Spreitzer, 1995), as a motivation factor to participate in new tasks implying the use of a smart technology. As aspects relating to improved capabilities with the use of a smart device (e.g., better control of energy consumption) can be assimilated to manifestations of the impact dimension of PE and threats to freedom of choice in the context of forced deployment can refer to a degradation of the self-determination dimension of the construct, it seems pertinent to consider PE in our context. Furthermore, despite the rich production of controversies regarding smart meters, no research has considered the impact of social representations, which may contribute to socially construct empowerment perceptions, on customers' use of smart technologies. As the theory of social representations (TSR) initiated by Moscovici (1961) can help explain concepts that lack a clear structure (Rodriguez et al., 2015) or reflect a universe of opinions (Moscovici, 1988), TSR seems appropriate for the study of objects subjected to mixed cognitions. In addition, as social representations have been seen in the literature as influencing behaviors, explaining, for instance, food choices (e.g., Makiniemi, Pirttila-Backman \& Pieri, 2011), they may help us to better explain smart technology use. In light of this, we propose in this research to explore the following question: to what extent do the social representations of Linky smart meters imposed by an organization reflect ambivalent customer psychological empowerment impacting their smart meter use? We propose to first explore to what extent the social representations of Linky smart meters capture elements corresponding to ambivalent psychological empowerment manifestations (Study 1); then, we investigate the link between the type of empowerment representations and the use of smart meters (Study 2).

Several contributions of this research can be emphasized. From a theoretical perspective, we first enrich the literature on customers' technology acceptance and self-service technology adoption with a motivational approach leveraging the conceptual background of psychological empowerment, which provides a more comprehensive understanding of antecedents of technology use in the context of forced deployment. Second, we extend previous research that highlighted the pertinence of social representations to understand objects subjected to mixed opinions, with the study of a controversial technology through the lens of the theory of social representations. Third, another originality of the present study lies in the way we linked the concept of psychological empowerment to the theory of social representations, clarifying how social representations could influence individuals' behaviors: indeed, socially constructed psychological empowerment representations actually constitute the antecedent of behavior. Finally, we propose in the present study a new method to assess the social acceptance of a new technology deployed by an organization, using social representations as a measurement tool. From a managerial perspective, by revealing an ambivalence around psychological empowerment representations impacting customers' expected participative use of a smart technology, we inform organizations on the importance of reinforcing positive psychological empowerment aspects. In addition, we suggest that organizations consider the emergence of specific negative social representations related to data privacy dissemination when imposing a technology enriched with artificial intelligence. 


\section{CONCEPTUAL BACKGROUND}

\section{Psychological Empowerment and Consumer Participation Involving the Use of a Smart Meter Psychological Empowerment Framework}

Traditionally, two approaches to empowerment have been used in the management literature. The first approach can be labeled a "structural" form of empowerment (Kanter, 1993) and considers empowerment afforded by the external context. Indeed, an organization can attempt to create the conditions where employees will feel a sense of empowerment. "Empowering Leadership" is a form of structural empowerment that has captured much research attention in management literature (Fong \& Snape, 2015; Lee et al., 2018; Zhang \& Bartol, 2010). The second approach, labeled the "psychological" approach, considers empowerment as a four-dimensional psychological state based on individuals' perceptions of meaningfulness, competence, self-determination, and impact (Spreitzer, 1995). This perspective focuses on the degree to which individuals actually feel empowered. Meaningfulness is derived from the notion of experienced meaningfulness of the work in Hackman and Oldham (1975) and represents the extent to which internalized personal values and beliefs fit the requirements of a job. Competence refers to beliefs about the extent to which one possesses the ability to perform tasks with skills that need to be successful (Bandura, 1989). The third dimension, self-determination, involves a sense of autonomy and control over the initiation, continuance, and regulation of a behavior (Deci \& Ryan, 1989). Consequently, individuals with self-determination have the freedom to select how to carry out their work (Quinn \& Spreitzer, 1997). Finally, the last dimension of psychological empowerment, impact, refers to the degree to which an individual believes he or she can influence or provoke changes in the outcomes of the organization (Seligman, 1975). The concept of psychological empowerment has also recently been used in the marketing literature to study consumer behavior and relationships with brands, specifically in the contexts of cocreation of innovation (Auh et al., 2019; Fuchs, Prandelli \& Schreier, 2010; Füller et al., 2009), health (Prigge, 2015), participation in social media activities (Buzeta, De Pelsmacker \& Dens, 2020; Saridakis et al., 2016), and, lately, self-service technologies (Schweitzer \& Simon, 2021).

The two approaches of empowerment are not opposite but linked, and psychological empowerment has long been studied as an outcome of structural empowerment (Maynard et al., 2012). A great deal of research has sought to understand the degree to which structural empowerment strategies actually translate into an employee's feeling of psychological empowerment. As evidenced by Seibert, Wang \& Courtright in their meta-analysis (2011, p.998), "feelings of empowerment are likely to be shaped by the organizational context, and in particular by management practices that delegate decision-making authority". In this paper, although we will choose to focus on psychological empowerment for the purpose of the study, we follow Linden et al.'s (2000) interactional perspective of psychological empowerment and consider the psychological dimensions of empowerment in relation to the social context (here, forced deployment) and the nature of the object itself (a technological device enriched with artificial intellligence). Thus, we acknowledge that perceptions of psychological empowerment may be based in part on external factors that surround individuals.

Accumulating empirical evidence has shown that psychological empowerment acts as a mediator of many positive outcomes. Over the last two decades, extensive research in organizational literature has documented the positive consequences of psychological empowerment by demonstrating that empowered employees perform better (Chen et al., 2007; Dust et al., 2014; Huang et al., 2009; Lee et al., 2017; Maynard et al., 2012; Seibert et al., 2011; Spreitzer, Kizilos, \& Nason, 1997), exhibit more organizational citizenship behaviors (Dust et al., 2014; Fong \& Snape, 2015; Huang et al., 2009; Lee et al., 2017; Seibert et al., 2011), and experience increased job satisfaction (Emery et al., 2019; Fong \& Snape, 2015; Laschinger et al., 2014; Liden, Wayne, \& Sparrowe, 2000; Seibert et al., 2011). In contrast, employees who are not empowered cannot, for example, "cope with organizational changes and respond passively" (Laschinger et al., 2014). In the marketing literature, psychological empowerment outcomes include the development of a more positive attitude towards the brand (Fuchs \& Schreier, 2011; Pranic \& Roehl, 2012), and increased demand and loyalty to the products/services of the company (Fuchs, Prandelli \& Schreier, 2010; Füller et al., 2009; Geyer-Schulz \& Meyer-Waarden, 2015; Hanson \& Yuan, 2018). 


\section{Consumer Participation Involving the Use of Smart Meters and Psychological Empowerment}

In the following, we explain further why we refer to psychological empowerment in the context of customer participation implying the use of a smart device, while this conceptual framework has largely been used in management literature in the context of work. First, as outlined by the sociology of work (e.g., Dujarier, 2014), customer participation in new tasks delegated by organizations might be considered consumer work, thus suggesting that customer motivation might be analyzed through the lens of frameworks traditionally used in the management field. In the context of Linky smart meter deployment, customers were introduced to a new technological device that would allow them to participate in the reduction of energy consumption. By extension, this situation could also be perceived as consumer work and thus mobilize psychological empowerment from management literature as a motivational factor to consider. In addition, as outlined in the literature by Wilson, Hargreaves \& Hauxwell-Baldwin (2017), the recent adoption of smart meters used to monitor energy consumption in smart homes is likely to reinforce customers' paradoxical cognitions, which include a loss of power due to a perceived threat to personal data control and, contrastingly, a sense of reinforced impact on their own consumption, which results from the high level of service customization provided by the smart device. These two observations can be referred to as ambivalent cognitions on the impact dimension of psychological empowerment. More generally, the functional benefits of using smart meters as communicated by the public organization Enedis (mainly more flexibility through remote employee interventions, possibility to monitor energy consumption and a connection to their own production of green electricity) can be tied to positive psychological empowerment manifestations on the dimensions of the construct relating to self-determination and impact. On the other hand, as outlined in the literature on self-service technology adoption, forcing consumers to use a technology-based self-service has proven to reduce their freedom to choose and give rise to perceptions of decisional control (Reinders, Dabholkar \& Frambach, 2008; Liu, 2012), which psychologists interpret as a reduction of individual self-determination.

\section{Social Representations}

Theoretical Background

The theory of social representation (TSR) initiated by Moscovici (1961) introduces the notion of socially constructed and shared knowledge, or the common sense of existing objects. In the TSR, the focus is on the social context in which consumers learn, perceive their environment and develop points of view rather than on the individual dimensions of attitude. Social representations allow individuals to interpret the practices of the different actors in their environment (public authorities, organizations, media, etc.). In this framework, concepts can be understood as "a form of knowledge socially developed and shared with practical designs and contributing to the construction of a reality common to a social group" (Jodelet, 1989, p. 36). Finally, social representations can be viewed as a system of interpretation of reality, which determines individuals' and groups' behaviors and practices (Abric, 1993, 2001; Rateau et al., 2011) with what is called by Jodelet (1989) the "already in mind."

Given that the TSR was introduced by Moscovici in 1961, several methods have been developed to investigate social representation content since then. In the present work, we follow the structural approach of social representation developed by Abric (2001). For the author, social representation constituent elements are linked together by relations; thus, "the analysis and comprehension of a concept through TSR necessarily involves a double identification both of its content and of its structure" (Abric, 1994, p. 19). The structure of a social representation is organized around two distinguishable cognitive systems. First, social representations comprise a central core, consisting of fewer and relatively abstract associations. That central core has two main functions: a function of generating the meaning and organizing the representation by influencing connections between other less important associations, thus gathering the "most important elements to undertake a task" (Abric, 1994, p.23); and a normative function of stabilizing the representation under altering environments where socioaffective, social or ideological dimensions are involved (Abric, 1994, p. 23). In that case, the central core provides relevant norms, behavioral action plans and stereotypes in certain situations. Second, social representations are composed of a peripheral system that supports the heterogeneity of the group, gives flexibility, has the function of allowing adaptation to reality and gives the 
possibility to integrate individual knowledge into the representation and protect the central system: "they constitute an interface between the central core and the actual situation in which the social representation is elaborated" (Abric, 1994, p. 25) and permit "a personalized modulation of representations and behaviors in a specific situation" (Abric, 1994, p. 27). Overall, the periphery is responsible for the concretization of the representation, and gradual changes in the social representation start on that periphery.

Indeed, social representations have the ability to evolve over time and circumstances, as highlighted in previous studies that took into account the dynamic nature of social representations (Alexandridis \& Maru, 2012; Pignon et al. 2017). Several authors in marketing literature have tried to transform social representation mainly through communication (Zbinden et al., 2011) and actions (Moliner, Joule \& Flament, 1995).

Smart Meters and the Theory of Social Representations: Social Representations as the Constituent Cognitions of an Object of Controversies and as a Measure of Social Acceptance

Many studies covering different fields of application have been conducted taking into account the influence of social representations on the perceptions of various objects: consumer behavior in food-related contexts (Bartels \& Reinders, 2010; Bostic, Sobal, \& Bisogni, 2018; Makiniemi, Pirttila-Backman \& Pieri, 2011; Mouret et al., 2013; Rodrigues et al., 2015), health (Pignon et al., 2017; Valdez-Tah et al., 2015) and social psychology (De Andrade \& Wachelke, 2011; Mullen, Calogero \& Leader, 2007). In the last decade, this framework has also begun to be widely used to approach mixed cognitions regarding controversial objects: burnout (Pawlowski, Kaganer \& Cater, 2007), unethical food (Makiniemi, Pirttila-Backman \& Pieri, 2011), psychological and physical diseases (Pignon et al., 2017; Valdez-Tah et al., 2015), drugs (Lopez, 2007), and fair price (Feybesse et al., 2020). Given that social representations can help explain concepts that are not well-defined or lack a clear structure (Rodriguez et al., 2015), reflecting a universe of opinions (Moscovici, 1988), TSRs have been considered appropriate for the study of objects subjected to mixed cognitions. As outlined by Moscovici (1961), the main condition for an object to be studied through the lens of TSR is to have dispersed information around the object linked to either an overwhelming amount or a total lack of communication given the complexity of or social barriers to the object. For these two reasons, the study of Linky smart meters seems well-suited to the use of TSR. Indeed, since the very beginning of its deployment in 2015, the object was a subject of controversies stemming from subversive "anti-Linky" groups and largely diffused in main media, while public authorities were trying to justify their deployment through the lens of energy consumption reduction motives. Thus, the "Linky smart meter" became a social symbol, with controversies providing a "common sense" (Abric, 1994) counterpart to the organization's communication and allowing most individuals to have, even briefly, some knowledge regarding the object. Consequently, we hypothesize that Linky descriptions might reflect implicit knowledge about smart meters and that the social representation approach might provide a framework for understanding the ambivalent cognitions around smart meters and their use.

In addition, in the last decade, the TSR has captured the attention of researchers in the field of public health management (HIV transmission prevention policies, vaccination programs, breastfeeding campaigns, etc.) (Ares et al., 2020; Winskell et al., 2020), seeking social legitimation of their policies to facilitate their implementation and citizen acceptance. In the case of our research object, while the public electricity distributor Enedis was putting its efforts into deploying smart meters to implement a smart grid for energy transition, at the same time, they were forced to bear the costs of polemics and their media treatment. Given that social representations reflect the shared perceptions of a group regarding an object, this approach seems especially well-suited to measure social acceptance and legitimation required for successful implementation.

After presenting and justifying the relevance of our conceptual frameworks, we formulate the following research questions:

RQ1: Do the social representations of Linky smart meters capture elements corresponding to ambivalent psychological empowerment manifestations? 
RQ2: How do ambivalent psychological empowerment representations impact customers' use of smart meters?

\section{METHOD}

The empirical part of this research comprises two consecutive phases aiming to answer the research questions and involves different qualitative and quantitative data collection and analysis methods. In the first exploratory phase to answer RQ1, the presence of ambivalent psychological empowerment representations regarding Linky smart meters is explored through an analysis of the structure of social representations, particularly adapted to the study of a controversial object and representing a good indicator of the acceptance of an implemented public policy, as outlined in the literature review. Then, in a second quantitative phase, an online questionnaire gathering items related to the identification of the structure of psychological empowerment social representations and measures relating to the level of feedback use provided by the smart meter was administered. This phase aimed to answer RQ2 by linking the types of psychological empowerment representations among three different groups, established from their levels of feedback use.

\section{Participants, Data Collection and Analysis \\ Phase 1}

In the first phase, a study of the structure of social representations was conducted, following Abric \& Vergès's (1994) plural-methodological approach in three stages: content identification, study of hierarchical evocation and control of the central core.

In the first stage, 70 individuals in an equal distribution of three age groups from 18 to 83 years old were recruited in France using the snowball sampling technique to collect the content of the representation. An open-ended associative task was proposed as suggested by Vergès (1992) to induce spontaneous evocations and collect references to the unconscious. Participants had to write down the first five words in the order that came to their minds after reading "Linky smart meter." The interviewers wrote down the answers provided by participants. In the first treatment aimed at reducing the number of collected associations, the words were lemmatized to be reduced to their root and classified in terms of synonymy to be grouped by theme using inductive coding. For example, the terms "consumption reporting" and "instantaneous consumption" were grouped under the same theme of "consumption tracking."

Then, as recommended by Vergès (1992), an analysis of the collected data based on hierarchized evocation was conducted in stage 2 , consisting of crossing the frequency of mentions of the categories and their average rank of appearance. Hierarchized evocation analysis allowed us to determine the salient elements of the representation, that is, those whose frequency of mention is the most important and that are among the first cited: those words have a high probability of representing the central core of the representation. This hierarchized evocation crossed analysis permitted us to obtain a repartition of the associative elements in four classes as illustrated in appendix 1, following Doise et al.'s (1993) methodology, corresponding to: 1) elements with a high probability of belonging to the central core; 2) peripheral elements corresponding to a "first periphery;" 3) contrasting elements probably reflecting representations of a subgroup; and 4) elements of the "second periphery."

As a third stage, an online questionnaire to assess the central core (centrality test) and confirm the structure of social representations, was made available to a selected French panel. A total of 270 respondents representative of the French population in two areas known for their advanced deployment of smart meters (South and West France), were recruited. Table 1 presents the characteristics of the participants in terms of gender, age, occupation, location, home ownership, and smart meter equipment. The results from stage 2 were used to create the questionnaire to control for the central core and followed Abric \& Vergès (1994), who recommend replacing the questions of the centrality test initiated by Moliner (1995) with affirmative questions. Thus, we kept the elements identified as belonging to the central core and periphery in the hierarchized analysis in phase 2 and proposed that the participants choose, for each element, one of the following items: a) This is Linky smart meters; b) It might be Linky smart meters; and c) This is Linky 
smart meters. This data collection procedure allowed us to calculate, for each element, a centrality score corresponding to the frequency of answers $\mathrm{a}, \mathrm{b}$ and $\mathrm{c}$ (see appendix 2). We finally considered that an element belonged to the central core of the representations when the results of this third stage revealed a number of positive (a) responses statistically higher $(\mathrm{p}<.05)$ than two-thirds of the respondents. This procedure is quite arbitrary but frequently used (Flament \& Rouquette, 2003).

TABLE 1

CHARACTERISTICS OF THE PARTICIPANTS OF PHASE 1

\begin{tabular}{|c|c|c|c|}
\hline \multirow[t]{2}{*}{ Criteria } & & \multicolumn{2}{|l|}{ Total } \\
\hline & & Number & $\%$ approximated \\
\hline \multirow[t]{2}{*}{ Gender } & Women & 165 & $61 \%$ \\
\hline & Men & 105 & $39 \%$ \\
\hline \multirow[t]{4}{*}{ Age } & Under 18 & 3 & $1 \%$ \\
\hline & $18 / 34$ & 58 & $21 \%$ \\
\hline & $35 / 54$ & 117 & $43 \%$ \\
\hline & $55+$ & 92 & $34 \%$ \\
\hline \multirow[t]{3}{*}{ Socioprofessional category } & $\mathrm{SPC}+$ & 78 & $32 \%$ \\
\hline & SPC - & 87 & $36 \%$ \\
\hline & Unemployed & 80 & $33 \%$ \\
\hline \multirow[t]{2}{*}{ Location } & South of France & 145 & $54 \%$ \\
\hline & West of France & 125 & $46 \%$ \\
\hline \multirow[t]{2}{*}{ Home ownership } & Yes & 145 & $71 \%$ \\
\hline & No & 58 & $29 \%$ \\
\hline \multirow[t]{3}{*}{ Equipped with Linky smart meter } & Yes & 203 & $75 \%$ \\
\hline & No & 47 & $17 \%$ \\
\hline & Don't know & 20 & $7 \%$ \\
\hline
\end{tabular}

Phase 2

This second phase consisted of a quantitative study permitting us to create groups based on the declared level of use of Linky smart meters and to examine the structure of social representations of these groups with the objective of comparing them. The level of use of the smart meter was a measure of the behavior of the participant regarding the feedback on electricity consumption provided through the device, since this represents the main accessible function for customers (Buchanan et al., 2015). The structure and predictive ability of social representations on smart meter feedback use were investigated using a questionnaire quantifying these aspects and containing several participant characteristics items such as occupation, main energy used in the house, regular behavior regarding ecology, etc. This questionnaire was administered after the first Covid pandemic confinement (June 2020) to a panel of French households of 203 respondents, with the selection criterion of being equipped with a Linky smart meter. A score for the level of use of the feedback based on the two questions "I have created a personal account on the interface of the energy provider to consult the feedback on my energy consumption" and "I have undertaken actions to reduce my energy consumption based on my feedback observations" was calculated and permitted us to cut the panel into three groups: nonuser (USE1), moderate user (USE2) and regular user (USE3). The structure of the social representations of each group was then analyzed, following the same methodology as in the third stage of Phase 1, consisting of calculating centrality scores for each element of the representation. Finally, these scores were compared for each group, as well as their sociodemographic characteristics, using means comparison tests complemented by multiple comparison tests (Fisher LSD tests) with the help of SPSS software. 
A summary of the overall research design is proposed in Table 2 below.

TABLE 2

RESEARCH DESIGN SUMMARY

\begin{tabular}{|c|c|c|}
\hline Phases & Research question & Method \\
\hline $\begin{array}{l}\text { Phase 1: structure } \\
\text { of social } \\
\text { representations }\end{array}$ & $\begin{array}{l}\text { RQ1: Do the social } \\
\text { representations of the Linky } \\
\text { smart meter capture elements } \\
\text { corresponding to ambivalent } \\
\text { psychological empowerment } \\
\text { manifestations? }\end{array}$ & $\begin{array}{l}\text { Procedure: Collection of } 70 \text { verbal associations } \\
\text { and } 270 \text { online surveys answers } \\
\text { Objective: Explore psychological empowerment } \\
\text { manifestations in the social representations of the } \\
\text { Linky smart meter } \\
\text { Analysis: Social representation structure analysis } \\
\text { in three stages: content identification, } \\
\text { hierarchical analysis, and centrality test. }\end{array}$ \\
\hline $\begin{array}{l}\text { Phase 2: social } \\
\text { representation } \\
\text { structure } \\
\text { comparison } \\
\text { among three } \\
\text { groups with } \\
\text { different levels of } \\
\text { feedback use }\end{array}$ & $\begin{array}{l}\text { RQ2: How do ambivalent } \\
\text { psychological empowerment } \\
\text { representations impact } \\
\text { customers' use of consumption } \\
\text { feedback? }\end{array}$ & $\begin{array}{l}\text { Procedure: } 203 \text { online surveys given to a panel } \\
\text { of French respondents equipped with Linky smart } \\
\text { meters } \\
\text { Objective: Identify a link between the type of } \\
\text { representations and the use of Linky smart meter } \\
\text { feedback. } \\
\text { Analysis: Centrality test and means comparative } \\
\text { tests. }\end{array}$ \\
\hline
\end{tabular}

\section{RESULTS}

Phase 1: General Structure of Social Representations of Linky Smart Meters in French Households

The results of the quantitative questionnaire (stage 3 in phase 1), which aimed to identify the structure of social representations regarding Linky smart meters, are illustrated in figure 1, and reveal elements of ambivalent psychological empowerment based on the four dimensions of the construct conceptualized by Spreitzer (1995).

First, in the central core illustrating elements that can be considered "the most important to undertake a given task" (Jodelet, 1989), we can observe psychological empowerment representations that can be assimilated to a self-determination ambivalence, entitled "Forced autonomy" in the figure, with the themes "Remote monitoring," "Organizational injunctions" and "Political subjugation." Indeed, these themes reveal a tension regarding the delegation of autonomy from public authorities to the customer in a context that is not chosen but forced. Considering that the peripheral zone of social representations has a role of concretization of the central core, this disempowerment in the self-determination dimension might be explained by the symbolic elements "Enedis" and "Inequitable exchange" in the peripheral system, precising that if consumers had the choice, they would probably refuse the installation of smart meters given the effort needed compared to the benefits.

Second, the content of the central core reveals ambivalent psychological empowerment manifestations in the meaning dimension of the construct, as highlighted by the elements "Novelty", "Modernity" and "Controversies". These elements can be considered as symbolic representations of technology use related to the construction of one's self identity. Indeed, previous literature on personal technologies adoption has shown that self-identity, signaling one's desired self through personal self-identity, is a strong symbolic determinant of technology acceptance since the personal self may be empowered when using new technologies (Arbore, Soscia \& Bagozzi, 2014). When considering using a new personal technology, the 
authors suggest that people evaluate its consistency with their desired self-identity. "Novelty" and "Modernity" can be considered as positive symbols of one's desired self-identity, contributing to a sense of uniqueness and status: indeed, possessions used by a majority of people do not necessarily provide clear signals of any particular identity, unlike innovations (Berger \& Heath, 2007). By definitions, new products are mastered by a minority of individuals, at least in the early stage of diffusion, and consequently hold great identity-signaling potential in relation to non-adopters. Liu et al. (2021) also outlined the symbolic potential of new smart vehicles adoption for expressing one's self-identity. However, as outlined by Arbore, Soscia \& Bagozzi (2014, p.90), symbols can also reveal a disempowering potential: "a symbolic value of a technology might also be negative, turning from facilitator of adoption into an impediment". The symbol "Controversies" associated to the smart meter can be considered as such: highlighted by the themes "Lack of information" and "Risk to the health" in the peripheral system, controversies counterbalance the empowering potential of smart meter use. Finally, symbolic meanings in the core center of representation of smart meters reflect what we might call a "Symbolic ambivalence of modernity".

Third, the two elements "Personal data disclosure" and "Consumption tracking" can be classified as ambivalent psychological empowerment manifestations with regard to the impact dimension of psychological empowerment, reflecting the "Ambivalence of artificial intelligence (AI)", specifically towards data privacy. On the one hand, "Personal data disclosure" outlines a degradation of psychological empowerment since the customer loses its ability to protect its privacy. On the other hand, "Consumption tracking" reveals a reinforcement of impact: indeed, themes of "Optimization," "Money savings" and "Ecology" in the peripheral system can transform into the reinforcement of psychological empowerment to the extent that consumption is tracked through Linky feedback.

Finally, we can observe the absence of the fourth psychological empowerment dimension in the central core, namely, competence. The thematic "Ease of use" in the peripheral system might be a sign that the ability to use smart devices is not a major concern.

The results of this first phase of the empirical design permit us to highlight, in response to RQ1, the presence of ambivalent psychological empowerment elements in the central core of social representations of French households within three dimensions of the construct (self-determination, meaning and impact), revealing forced autonomy, symbolic ambivalence of modernity, and ambivalence of artificial intelligence. Only the competence dimension is absent from the central core. Although we focused on ambivalence within dimensions of psychological empowerment, potential psychological empowerment ambivalence regarding Linky smart meters could also emerge between dimensions, such as in the case of a privacy paradox balancing the benefits of autonomy (increased self-determination) to personal data disclosure (impact degradation). 


\section{FIGURE 1}

\section{STRUCTURE OF SOCIAL REPRESENTATIONS OF LINKY SMART METER}

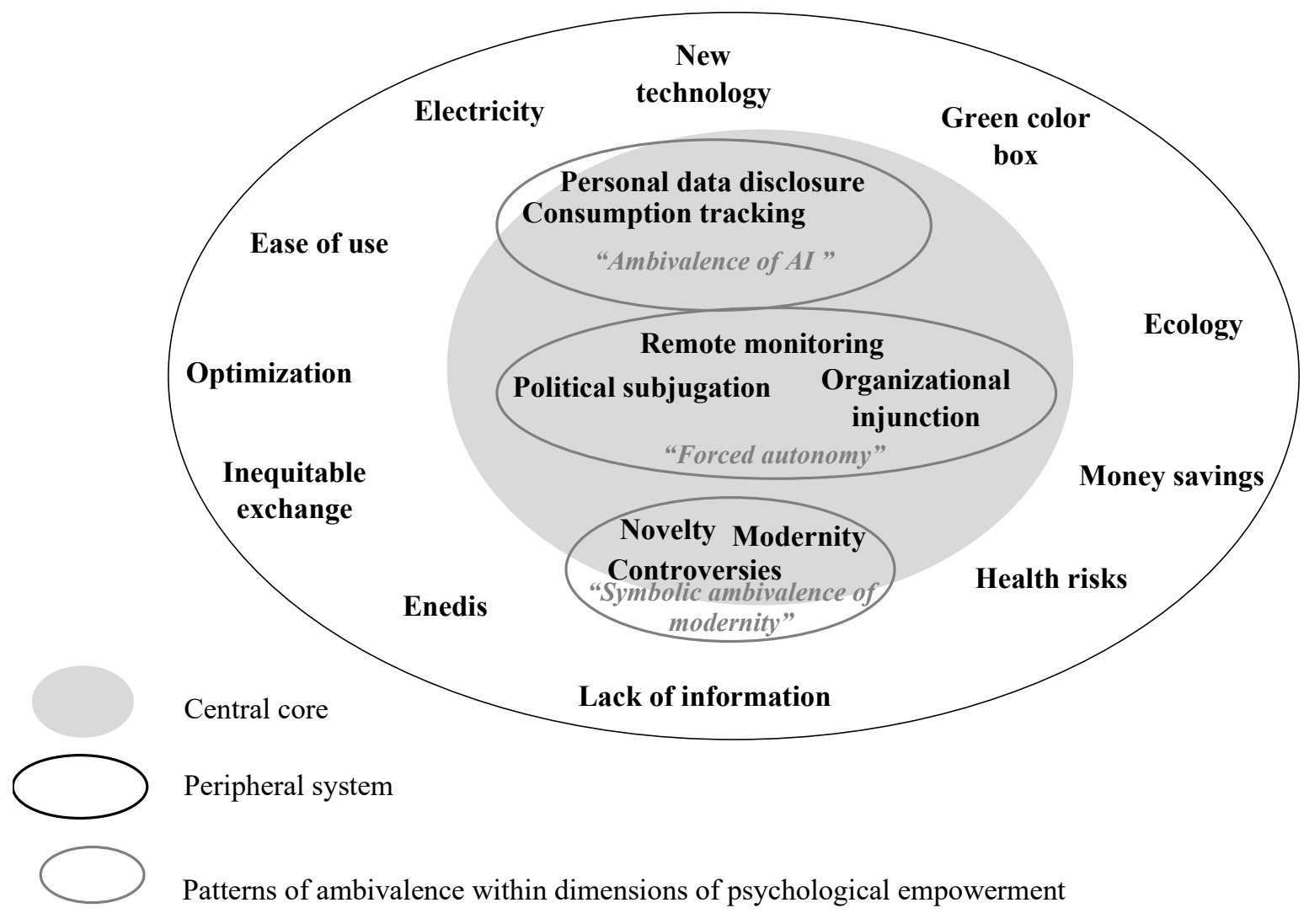

\section{Phase 2: The Structural Composition and Comparison of Social Representations Among Households With Different Levels of Smart Meter Feedback Use}

The aim in the second phase was to explore a link between social representations of Linky smart meters and the use of feedback (different levels of use) and to compare the structure of social representations, specifically ambivalent patterns identified in phase 1 , as well as sociodemographic characteristics between defined groups by considering their level of feedback use (nonuser, moderate user and regular user). Tables 3 and 4 illustrate the results.

First, according to social representation literature, the stable central core is strongly marked by the collective memory of a given group and the standards to which it refers. Consequently, we focused our analysis of the structure on identifying the similarities and differences in the elements of that central core among the three groups before looking at sociodemographic specificities of the groups. The number of core elements in the three groups is quite similar, varying from 10 to 11 . Only ambivalence patterns of selfdetermination and meaning related to Linky smart meters identified in phase 1, entitled "forced autonomy" and "symbolic ambivalence of modernity," are core ambivalent patterns in the three groups, which indicates that these patterns are the only stable elements in the representation regardless of the level of use. However, ambivalence in the impact dimension involving personal data disclosure and consumption tracking, labeled "ambivalence of artificial intelligence" in phase 1, is specific to the groups of non- and moderate users, with higher centrality of the representation "Personal data disclosure" for nonusers. For this group, the element "Controversies" of the "symbolic ambivalence of modernity" pattern is also more central than for the two other groups, and their central core also includes the representation "Health risks," which is absent from the core social representations of the two other groups. This observation outlines the influence of the controversial content on their representations of the object compared to the other groups. For regular users, 
the most prevalent difference in the structure of social representations is the core position of the elements "Ecology" and "Money savings" that are peripheral elements for non- and moderate users. These findings resonate with previous studies on consumers' motives to engage in energy consumption reduction, which highlighted the prevalence of financial and environmental motives (Buchanan et al., 2014; Hargreaves et al., 2010).

Second, we compared the sociodemographic characteristics of the three groups of users. Few significant differences could be observed. Though, the group of regular users (USE3), which is the smallest sample $(\mathrm{N}=40)$, has the particularity to gather more workers from higher professional positions. The group of nonusers (USE1), comprising a large majority of participants $(\mathrm{N}=102)$, is characterized by less adoption of ecologically conscious behaviors in their daily routines and is also the one who relies the most on sources of energy other than electricity in their homes (gas, wood, etc.).

In response to RQ2, the results of this second phase show that only the pattern of ambivalence within the impact dimension of psychological empowerment identified in phase 1, namely, the "ambivalence of artificial intelligence" pattern, seems to negatively influence the use of the smart meter. However, the results also outline that isolated negative psychological empowerment elements or ambivalent patterns' influence on the use of the smart device might be compensated between dimensions by positive psychological empowerment manifestations, specifically the elements of "Ecology" and "Money savings" related to the impact dimension.

TABLE 3

SOCIAL REPRESENTATIONS PATTERNS AND FEEDBACK USE

\begin{tabular}{|c|c|c|c|c|}
\hline $\begin{array}{l}\text { Mean scores* of } \\
\text { psychological } \\
\text { empowerment social } \\
\text { representations }\end{array}$ & $\begin{array}{l}\text { Feedback } \\
\text { nonusers } \\
(\mathrm{N}=102) \\
\text { USE1 }\end{array}$ & $\begin{array}{l}\text { Feedback } \\
\text { moderate } \\
\text { users }(\mathrm{N}=61) \\
\text { USE2 }\end{array}$ & $\begin{array}{l}\text { Feedback } \\
\text { regular } \\
\text { users } \\
(\mathrm{N}=40) \\
\text { USE3 }\end{array}$ & $\begin{array}{l}\text { Significance of score } \\
\text { differences ( } t \text { tests) }\end{array}$ \\
\hline \multicolumn{5}{|c|}{ "Symbolic ambivalence of modernity" pattern } \\
\hline "Modernity" & 1,34 & 1,16 & 1,10 & $\begin{array}{l}\text { Nonusers vs Moderate } \\
\text { Users: } F=4,957 ; p<.019 \\
\text { Nonusers vs Users: } \\
F=4,957 ; p<.007\end{array}$ \\
\hline "Controversies" & 1,19 & 1,23 & 1,43 & $\begin{array}{l}\text { Nonusers vs Users: } \\
F=3,045 ; p<.016\end{array}$ \\
\hline "Novelty" & 1,08 & 1,11 & 1,10 & NS \\
\hline \multicolumn{5}{|l|}{ "Forced autonomy" pattern } \\
\hline "Organizational injunction" & 1,26 & 1,26 & 1,28 & NS \\
\hline "Remote monitoring" & 1,11 & 1,15 & 1,20 & NS \\
\hline "Political subjugation" & 1,22 & 1,16 & 1,18 & NS \\
\hline \multicolumn{5}{|c|}{ "Ambivalence of AI" pattern } \\
\hline "Personal data disclosure" & 1,28 & 1,42 & 1,50 & $\begin{array}{l}\text { Nonusers vs Users: } \mathrm{F}=- \\
2,305 ; \mathrm{p}<.05\end{array}$ \\
\hline "Consumption tracking" & 1,13 & 1,13 & 1,08 & NS \\
\hline \multicolumn{5}{|c|}{ Other empowerment manifestations (not related to ambivalent patterns identified in phase 1) } \\
\hline "Ecology" & 2,09 & 1,79 & 1,28 & $\begin{array}{l}\text { Nonusers vs Moderate } \\
\text { Users: } F=19,491 ; p<.009\end{array}$ \\
\hline
\end{tabular}




\begin{tabular}{|c|c|c|c|c|}
\hline & & & & $\begin{array}{l}\text { Moderate users vs Users: } \\
\mathbf{p}<.000 \\
\text { Nonusers vs Users: } \mathbf{p}<.000\end{array}$ \\
\hline "Money savings" & 2,09 & 1,77 & 1,38 & $\begin{array}{l}\text { Nonusers vs Moderate } \\
\text { Users: } F=15,399 ; p<.006 \\
\text { Moderate users vs Users: } \\
p<.006 \\
\text { Nonusers vs Users: } p<.000 \\
\end{array}$ \\
\hline "Ease of use" & 1,48 & 1,24 & 1,15 & $\begin{array}{l}\text { Nonusers vs Moderate } \\
\text { Users: } F=6,985 ; p<.007 \\
\text { Nonusers vs Users: } \mathbf{p}<.001\end{array}$ \\
\hline "Green color box" & 1,41 & 1,42 & 1,45 & NS \\
\hline "New technology" & 1,46 & 1,39 & 1,30 & NS \\
\hline "Health risks" & 1,86 & 1,97 & 2,05 & NS \\
\hline "Dangerous" & 1,98 & 2,15 & 2,25 & NS \\
\hline "Enedis" & 1,45 & 1,53 & 1,45 & NS \\
\hline $\begin{array}{l}\text { "Inequitable } \\
\text { exchange" }\end{array}$ & 1,55 & 1,53 & 1,70 & NS \\
\hline "Lack of information" & 1,79 & 1,84 & 1,83 & NS \\
\hline
\end{tabular}

Social representations belonging to the central

NS $=$ Not significant core

*mean scores from the questionnaire in phase 2 (score from 1 to 3, 1 revealing higher centrality)

\section{TABLE 4}

\section{SOCIO-DEMOGRAPHIC CHARACTERISTICS AND FEEDBACK USE}

\begin{tabular}{|c|c|c|c|c|}
\hline & $\begin{array}{l}\text { Feedback } \\
\text { nonusers } \\
(\mathrm{N}=102) \\
\text { USE1 }\end{array}$ & $\begin{array}{l}\text { Feedback } \\
\text { moderate } \\
\text { users } \\
(\mathrm{N}=61) \\
\text { USE2 }\end{array}$ & $\begin{array}{l}\text { Feedback } \\
\text { regular } \\
\text { users } \\
(\mathrm{N}=40) \\
\text { USE3 }\end{array}$ & $\begin{array}{l}\text { Significance of score differences } \\
\text { (t tests) }\end{array}$ \\
\hline $\begin{array}{l}\text { Owns a smart meter since } \\
\text { (mean) }\end{array}$ & $\begin{array}{l}19,6 \\
\text { months }\end{array}$ & $\begin{array}{l}16 \\
\text { months }\end{array}$ & $\begin{array}{l}13,2 \\
\text { months }\end{array}$ & $\begin{array}{l}\text { Nonusers vs Moderate: } F=3,147 ; \\
p<.034\end{array}$ \\
\hline & $\begin{array}{l}\text { Yes : } \\
54,9 \%\end{array}$ & $\begin{array}{l}\text { Yes: } \\
68,9 \%\end{array}$ & Yes : $65 \%$ & \\
\hline $\begin{array}{l}\text { Is electricity the main source of } \\
\text { energy? }\end{array}$ & $\begin{array}{l}\text { No : } \\
41,2 \% \\
\text { Dnk : } \\
3,9 \%\end{array}$ & $\begin{array}{l}\text { No: } \\
31,1 \%\end{array}$ & No : $35 \%$ & $\begin{array}{l}\text { Nonusers vs Moderate: } F=-3,428 ; \\
p<.010\end{array}$ \\
\hline \multirow{7}{*}{$\begin{array}{l}\text { Adopts ecologically conscious } \\
\text { behaviors (ECB) }\end{array}$} & Yes: & & & \multirow{7}{*}{$\begin{array}{l}\text { Nonusers vs Moderate: } F=-7,479 ; \\
p<.000\end{array}$} \\
\hline & $5,9 \%$ & $11,5 \%$ & $42,5 \%$ & \\
\hline & No: & No: & No: & \\
\hline & $92,2 \%$ & $86,9 \%$ & $57,5 \%$ & \\
\hline & $\begin{array}{l}\text { Dnk : } \\
1,9 \%\end{array}$ & $\begin{array}{l}\text { Dnk : } \\
1,6 \%\end{array}$ & & \\
\hline & No: & No: & No: & \\
\hline & $27,5 \%$ & $32,8 \%$ & $25 \%$ & \\
\hline
\end{tabular}




\begin{tabular}{|c|c|c|c|c|c|}
\hline \multirow{4}{*}{ 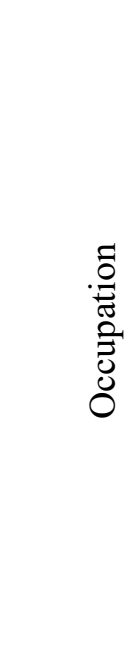 } & $\begin{array}{l}\text { Executive from a } \\
\text { public or private } \\
\text { organization or } \\
\text { liberal profession }\end{array}$ & $6,90 \%$ & $8,20 \%$ & $10 \%$ & $\begin{array}{l}\text { Moderate vs Users: } F=16,534 ; \\
p<.000 \\
\text { Nonusers vs Users: } p<.000\end{array}$ \\
\hline & $\begin{array}{l}\text { Intermediate } \\
\text { profession/artisan/ } \\
\text { salesman }\end{array}$ & $18,60 \%$ & $18 \%$ & $25 \%$ & NS \\
\hline & Employee/worker & $42,10 \%$ & $28 \%$ & $27,50 \%$ & NS \\
\hline & $\begin{array}{l}\text { Unemployed, } \\
\text { retired }\end{array}$ & $31,30 \%$ & $38 \%$ & $27,50 \%$ & NS \\
\hline \multicolumn{2}{|c|}{ Age (average) } & 51 & 47 & 48 & NS \\
\hline \multicolumn{2}{|c|}{ Nbr of people in the home } & 2,6 & 2,6 & 2,9 & NS \\
\hline \multirow[b]{2}{*}{ Gender } & $\%$ of men & $38,20 \%$ & $37,70 \%$ & $47,50 \%$ & \multirow[b]{2}{*}{ NS } \\
\hline & $\%$ of women & $61,80 \%$ & $62,30 \%$ & $52,50 \%$ & \\
\hline \multicolumn{2}{|c|}{ Owner of the home? } & $\begin{array}{l}\text { Yes: } \\
72,5 \% \\
\text { No : } \\
27,5 \%\end{array}$ & $\begin{array}{l}\text { Yes: } \\
67,2 \% \\
\text { No: } \\
32,8 \%\end{array}$ & $\begin{array}{l}\text { Yes: } \\
75 \% \\
\text { No: } \\
25 \%\end{array}$ & NS \\
\hline
\end{tabular}

\section{DISCUSSION}

This study accepted the forced installment of smart meters in customers' homes, delivering electricity consumption feedback, as a way for an organization to engage individuals in the management of their electricity consumption. Our objectives were to examine the extent to which social representations of the smart meter reflected ambivalent customer psychological empowerment and to explore the links between the content and structure of social representations and smart meter use. For this purpose, we first investigated social representations of the "Linky smart meter" among French households, employing the free word association procedure, hierarchized content and the centrality test to reveal the content and structure of these representations. Then, we used a quantitative questionnaire to identify user groups among French households equipped with Linky smart meters and controlled for the central core of representations to compare the social representation structure among the groups.

To answer our first research question, we observed ambivalent psychological empowerment elements in the central core of social representations of French households, revealing a forced autonomy (paradoxical self-determination), a symbolic ambivalence of modernity (paradoxical meaning), and an ambivalence of artificial intelligence (paradoxical impact). We found no evidence of ambivalence in the competence dimension.

In relation to our second research question, we observed that the social representations of Linky smart meters among the three groups were organized quite differently. Among all groups, Linky smart meters tend to be perceived as a form of new technological device reinforcing, on the one hand, their psychological empowerment by giving users a chance to be autonomous and track their energy consumption while reducing, on the other hand, their empowerment, a consequence of organization's forced deployment and 
threat to their privacy. As it comes to differences, the results showed that, overall and not surprisingly, the users had a more positive perception of Linky smart meters in regard to psychological empowerment dimensions, while the nonusers had a more negative view. The nonusers appeared to be more affected by symbolic controversies (health risks) and concerned with threats to the impact dimension of psychological empowerment, specifically personal data disclosure, while the users emphasized positive impacts, namely, money savings and ecology. These findings have implications in a variety of ways that will be further developed below.

\section{Theoretical and Methodological Contributions}

First, they contribute to enriching the literature on information systems and customers' technology acceptance as well as the literature on self-service technology adoption with a motivational approach leveraging the conceptual background of psychological empowerment, which provides a more comprehensive understanding of factors influencing technology use in the context of forced deployment. Specifically, our approach to customer motivation through the lens of psychological empowerment permits to investigate ambivalent perceptions regarding a technology enriched with artificial intelligence and imposed by an organization. Furthermore, in the field of energy economics, our results contribute to the recent critical discussion on individuals' motivations to use smart technologies and engage in consumption reduction behaviors. Indeed, several authors have called for research to explain the gap between customers' expected participation and their actual behaviors regarding energy consumption reduction (Buchanan et al., 2014, 2015; Mc Kenna et al., 2013; Strengers, 2013). As outlined by Shove \& Walker (2014), traditional cost benefit analysis in this type of decision-making approach is questionable given that consumers do not use energy for their own sake but rather as a byproduct of everyday activities. Our lens of psychological empowerment provides an explanation for deficient customer participation in energy consumption reduction given the lack of consideration for customer psychological empowerment when deploying smart meters in private homes.

Second, we extend previous literature that highlighted the pertinence of the theory of social representations to understand objects subjected to mixed opinions, with the study of a particular controversial object through the lens of social representations. As shown by our results, this theoretical framework is clearly appropriate. Indeed, it permits to explore a specific object lacking a clear structure while reaching some ambivalent, even opposite, cognitions: our results show that at the central core of social representations, both positive elements related to customers' possibilities to track their energy consumption and negative elements mainly regarding personal data disclosure, political subjugation and organizational injunction, can coexist. Social representations study offers the possibility to identify specific patterns of ambivalence within the central core, thus giving a more comprehensive view of which elements remain unclear to individuals.

Third, the originality of the present study lies in the way we linked the concept of psychological empowerment to the theory of social representations, clarifying the link between social representations and individuals' behaviors. Previous studies in consumer behavior, especially in food-related contexts, have considered the influence of social representations on food choices (Bartels \& Reinders, 2010; Bostic, Sobal, \& Bisogni, 2018; Makiniemi, Pirttila-Backman \& Pieri, 2011; Mouret et al., 2013; Rodrigues et al., 2015), but no explanation of how social representations may influence behavior was provided. Mainly, social representations associated with an object were considered a reflection of the values and norms adopted by a particular group of individuals, consequently influencing the overall acceptance. In this study, we show that psychological empowerment representations can be socially constructed and that these constitute an antecedent of behaviors instead of the traditional approach of values and norms. Indeed, in the specific context of smart meter use, negative/positive psychological empowerment social representations are related to a decreased/increased use of the object.

Finally, we propose in the present study to assess the social acceptance of an initiative deployed by an organization and relying on customer implications for new tasks, using social representations as a

measurement tool. The use of social representations to evaluate potential gaps and areas of intervention in policy-making is not new - although it is recent—for public management academics, mainly in the area of 
public health (e.g., Ares et al., 2020). In this field, the authors showed that focusing on social representations of a specific object permits to address the question of successful implementation of public policies and to fully understand customers' reactions to new policies. Consequently, we suggest that organizations consider more systematically social representations associated with their new projects, such as the deployment of a smart technology, before investing substantial amounts of funds.

\section{Managerial Implications}

This section proposes prospective pathways for translating the obtained results into instruments for organizations, employing the lenses of both the empowerment framework from management literature and social representations theory.

One of the interesting findings of the present work is the relevance of the psychological empowerment framework for examining consumers' representations of smart technologies when their deployment is not a choice but imposed by an organization. Consequently, organizations seeking to increase consumer participation should take into account the need to facilitate the emergence of positive psychological empowerment perceptions with regard to their participative objectives and the smart object itself. In management literature, two meta-analytic reviews (Maynard, Gilson, \& Mathieu, 2012; Seibert, et al., 2011) have highlighted the antecedents of psychological empowerment, especially the implementation of structural empowerment strategies by managers, purported to influence perceptions of psychological states (Conger \& Kanungo, 1988) and intrinsic work motivation (Thomas \& Velthouse, 1990). Among these strategies, shared and increased information has proven to foster empowerment (Spreitzer, 1995; Srivastava, Bartol, \& Locke, 2006), helping employees better understand how they can contribute to corporate goals and facilitating feelings of competence in their work roles (Seibert, et al., 2011). We assume that, by contrast, forced deployment coupled with a lack of communication has a negative impact on empowerment. (e.g., when management transfers autonomy and responsibility from management to lowerlevel employees). Thus, in our context, organizations should launch upstream informational transparent communication campaigns to raise individuals' awareness of their collective objectives. Another strategy implemented in the management literature to foster psychological empowerment is to increase the degree to which subordinates participate in decision-making (Sashkin, 1976). Consequently, to increase customers' adhesion to a collective objective, organizations should set up regular mechanisms for dialogue that would enable individuals to express their opinions, ideas and worries. The French government, which created social citizen dialog bodies in 2019 with the aim of formulating improvement proposals regarding global warming, underlying its intention to develop a more participative democracy, could be an inspiring example to follow. As a result, in February 2021, a "Citizens' Agreement for Climate," written by a participative democracy assembly of 150 citizens drawn by lot, defined structural measures to reach a reduction of greenhouse gas emissions by at least $40 \%$ until 2030, taking into account social equity.

Another interesting finding of this study for organizations is the content of ambivalent psychological empowerment patterns influencing the use of smart devices. Indeed, the results outlined the strength of the ambivalence of artificial intelligence towards privacy among nonuser representations, while regular users had more positive psychological empowerment representations regarding smart meter use, such as money savings and ecological motives. Considering the dynamic nature of social representations, energy suppliers should try to compensate for the negative psychological empowerment patterns associated with the use of smart meters based on positive psychological empowerment elements observed among regular users. In the literature, two strategies have traditionally been used to transform social representations: communication campaigns (Pignon et al., 2017; Zbinden et al., 2011) and the creation of conditions of commitment (Moliner, Joule et Flament, 1995) based on theories of thinking and freely given consent by Joule et Beauvois (1998). Considering the deficient communication from Enedis when deploying the smart technology, shown by the element "Lack of information" in our results, we choose to focus our recommendations on this axis. As previous literature has shown that communication about core elements of social representations rather than peripheral ones is more convincing (Barbier et al, 2020; Zbinden et al., 2011), specific communication on the two key positive aspects of psychological empowerment in the core representations of users, that is, money saving and ecology, may help to increase confidence in the smart 
device. Communications campaigns jointly executed by private energy suppliers and the public energy distributor could be undertaken. First, energy suppliers' information stressing the financial personal benefits in monitoring energy consumption should be provided to customers to allow for informed decisions and adequate use of the device. We particularly suggest relying on testimonies from peers who used consumption feedback to reduce their electricity bill to share on social media as a way to generate positive word-of-mouth. In parallel, educational public campaigns stressing the importance of participation in collective energy consumption reduction (ecological concerns) should be implemented to encourage ecological citizenship behaviors. As outlined by our results, users of smart meters generally adopt more ecologically conscious behaviors compared to nonusers, which resonates with Wallenborn et al.'s (2011) findings that only households that were already interested or involved in energy savings were willing to use energy monitors and learn from them. However, it is important to stress that public communication campaigns involving education on more ecological behaviors should be designed with great care to avoid increasing the moral pressure already surrounding the forced deployment of smart meters.

\section{Limitations and Future Research}

Despite the interesting findings of this research, some potential limitations can be identified, suggesting opportunities for future research. First, this research was exploratory in nature and requires more systematic investigation through quantitative generalization. Experimental designs could investigate different communication campaigns (monetary savings versus ecology focused) and their impact on the transformation of social representations of smart meters. Additionally, longitudinal designs would be interesting to analyze how the representations of the smart meter may evolve to identify the potential impact of regular use over time. Indeed, as outlined by previous literature on energy economics, there are indications that consumers' engagement with in-home technologies may lessen over time (Ueno et al., 2006; Van Dam et al., 2010). Additionally, the conceptual framework used in this research, that is, the analysis of psychological empowerment through the lens of social representation theory, could be transposed into other contexts. As our work targeted a French context, it is necessary to evaluate its generalizability in different European countries as well as American or Asian cultures.

\section{CONCLUSION}

The European Directive of July 13th, 2009 enacted the deployment of smart meters by member states in anticipation that it would help customers optimize and reduce their electricity consumption. In France, a public organization was mandated to deploy smart meters in households and increase customers' participation. More broadly, the present work explores how an organization can facilitate customer participation in new tasks, specifically when they require the use of smart technology. Specifically, the study presents customers' psychological empowerment representations of a smart device in a context of forced deployment and its impact on the use of the object based on a social representation analysis. It finds ambivalent psychological empowerment elements in the central core of social representations of French households, with one pattern of ambivalence particularly impacting smart meter use: the ambivalence of artificial intelligence in smart technologies related to data privacy concerns. This study suggests that even when you might think your status as a public organization legitimates your intervention, you should still consider customers' psychological empowerment as a motivating factor in the deployment of a smart device which implies their participation in new tasks. Structural empowerment strategies and specific communication campaigns should be considered by organizations to reduce hindrances to achieving extended customer participation in new tasks involving the use of AI-enabled smart devices. 


\section{REFERENCES}

Abrahamse, W., Steg, L., Vlek, C., \& Rothengatter, T. (2007). The effect of tailored information, goal setting, and tailored feedback on household energy use, energy-related behaviors, and behavioral antecedents. Journal of Environmental Psychology, 27, 265-276.

Abric, J.C. (1993). Central system, peripheral system: Their functions and roles in the dynamic of social representations. Papers on Social Representations, 2, 75-78.

Abric, J.C. (1994). Pratiques sociales et représentations.

Abric J.C. (2001). A structural approach to social representations. In K. Deaux \& G. Philogène (Eds.), Representations of the social: bridging theoretical traditions (pp. 42-47). Oxford: Blackwell.

Abric, J.C., \& Verges, P. (1994). La représentation sociale de la banque. Aix-en-Provence, Etudes et recherches du gifresh.

Alexandridis, K., \& Maru, Y. (2012). Collapse and reorganization patterns of social knowledge representation in evolving semantic networks. Information Sciences, 200, 1-21.

Andrade, A., Wachelke, J., \& Howat-Rodrigues, A. (2015). Relationship satisfaction in young adults: Gender and love dimensions. Interpersona, 9, 19-31.

Arbore, A., Soscia, I., \& Bagozzi, R.P. (2014). The role of signaling identity in the adoption of personal technologies. Journal of the Association of Information System, 15(2), 1.

Ares, G., Girona, A., Rodríguez, R., Vidal, L., Iragola, V., Machín, L., \& Bove, I. (2020). Social representations of breastfeeding and infant formula: An exploratory study with mothers and health professionals to inform policy making. Appetite, 151, 104683.

Auh, S., Menguc, B., Katsikeas, C.S., \& Jung, Y.S. (2019). When does customer participation matter? An empirical investigation of the role of customer empowerment in the customer participationperformance link. Journal of Marketing Research, 56(6), 1012-1033.

Avolio, B.J., Gardner, W.L., Walumbwa, F.O., Luthans, F., \& May, D.R. (2004). Unlocking the mask: A look at the process by which authentic leaders impact follower attitudes and behaviors. The Leadership Quarterly, 15(6), 801-823.

Barbier, M., Moták, L., Gasquet, C.D., Girandola, F., Bonnardel, N., \& Monaco, G.L. (2020). Social representations and interface layout: A new way of enhancing persuasive technology applied to organ donation. PLOS ONE, 15(12), e0244538.

Bartels, J., \& Reinders, M.J. (2010). Social identification, social representations, and consumer innovativeness in an organic food context: A cross-national comparison. Food Quality and Preference, 21(4), 347-352.

Beauvois, J-L., \& Joule, R-V. (1998). La soumission librement consentie. (S.1.): Presses Universitaires de France.

Berger, J.A., \& Heath, C. (2007). Where consumers diverge from others: identity signaling and product domains. Journal of Consumer Research, 34(2), 121-134.

Blut, M., Wang, C., \& Schoefer, K. (2016). Factors influencing the acceptance of self-service technologies: A meta-analysis. Journal of Service Research, 19.

Bostic, S.M., Sobal, J., \& Bisogni, C.A. (2018). Social representations of fish and seafood among midlife rural adults: Benefits, risks, and involvement. Food Policy, 76(C), 99-108.

Buchanan, K., Russo, R., \& Anderson, B. (2014). Feeding back about eco-feedback: How do consumers use and respond to energy monitors? Energy Policy, 73, 138-146.

Buchanan, K., Russo, R., \& Anderson, B. (2015). The question of energy reduction: The problem(s) with feedback. Energy Policy, 77, 89-96.

Buzeta, C., De Pelsmacker, P., \& Dens, N. (2020). Motivations to Use Different Social Media Types and Their Impact on Consumers' Online Brand-Related Activities. Journal of Interactive Marketing, 52, 79-98.

Chen, Z., Lam, W., \& Zhong, J. (2007). Leader-member exchange and member performance: A new look at individual-level negative feedback-seeking behavior and team-level empowerment climate. The Journal of Applied Psychology, 92, 202-12. 
Conger, J.A., \& Kanungo, R.N. (1988). The empowerment process: Integrating theory and practice. The Academy of Management Review, 13(3), 471-482.

Dabholkar, P., Bobbitt, L., \& Lee, E-J. (2003). Understanding consumer motivation and behavior related to self-scanning in retailing: Implications for strategy and research on technology-based selfservice. International Journal of Service Industry Management, 14, 59-95.

Darby, S. (2006). The effectiveness of feedback on residential energy consumption. A review for DEFRA of the literature on metering, billing and direct displays. Environmental Change Institute, University of Oxford.

Davis, F., Bagozzi, R., \& Warshaw, P. (1989). User acceptance of computer technology: A comparison of two theoretical models. Management Science, 35, 982-1003.

Deci, E.L., Connell, J.P., \& Ryan, R.M. (1989). Self-determination in a work organization. Journal of Applied Psychology, 74(4), 580-590.

Ding, X., Hu, P., \& Sheng, O. (2011). e-SELFQUAL: A scale for measuring online self-service quality. Journal of Business Research, 64, 508-515.

Doise, W., Clemence, A., \& Lorenzi-Cioldi, F. (1993). The quantitative analysis of social representations. Hemel Hempstead, Harvester Wheatsheaf.

Dujarier, M.-A. (2014). The three sociological types of consumer work. Journal of Consumer Culture, 16.

Dust, S., Resick, C., \& Mawritz, M. (2014). Transformational leadership, psychological empowerment, and the moderating role of mechanistic-organic contexts. Journal of Organizational Behavior, 35 .

Emery, C., Booth, J.E., Michaelides, G., \& Swaab, A.J. (2019). The importance of being psychologically empowered: Buffering the negative effects of employee perceptions of leader-member exchange differentiation. Journal of Occupational and Organizational Psychology, 92(3), 566-592.

Feybesse, C., Lubart, T., Rasa, L., Ossom, C., Cavasino, V., Jacob, J., \& Lemonnier, T. (2020). Social representation of fair price among professional photographers. PLOS ONE, 15.

Fischer, C. (2008). Feedback on household electricity consumption: A tool for saving energy? Energy Efficiency, 1(1), 79-104.

Flament, C., \& Rouquette, M. (2003). Anatomie des idées ordinaires: Comment étudier les représentations sociales. Paris: Armand Colin.

Fong, K.H., \& Snape, E. (2015). Empowering leadership, psychological empowerment and employee outcomes: Testing a multi-level mediating model. British Journal of Management, 26(1), 126-138.

Fuchs, C., Prandelli, E., \& Schreier, M. (2010). The psychological effects of empowerment strategies on consumers' product demand. Journal of Marketing, 74.

Fuchs, C., \& Schreier, M. (2011). Customer empowerment in new product development. Journal of Product Innovation Management, 28(1), 17-32.

Füller, J., Mühlbacher, H., Matzler, K., \& Jawecki, G. (2009). Consumer empowerment through internetbased co-creation. Journal of Management Information Systems, 26, 71-102.

Geyer-Schulz, A., \& Meyer-Waarden, L. (2015). Consumer Empowerment: Is the digital consumer a happy consumer. Karlsruher Institute für Technologie (KIT), Karlsruhe.

Hackman, J.R., \& Oldham, G.R. (1975). Development of the job diagnostic survey. Journal of Applied Psychology, 60(2), 159-170.

Hanson, S., \& Yuan, H. (2018). Friends with benefits: Social coupons as a strategy to enhance customers' social empowerment. Journal of the Academy of Marketing Science, 46(4), 768-787.

Hargreaves, T., Nye, M., \& Burgess, J. (2010). Making energy visible: A qualitative field study of how householders interact with feedback from smart energy monitors. Energy Policy, 38, 6111-6119.

Huang, X., Iun, J., Liu, A., \& Gong, Y. (2009). Does participative leadership enhance work performance by inducing empowerment or trust? The differential effects on managerial and non-managerial subordinates. Journal of Organizational Behavior, 31, 122-143.

Jodelet, D. (1989). Représentations sociales: Un domaine en Expansion. In D. Jodelet (Ed.), Les Représentations Sociales. Paris: Presses Universitaires de France. 
Kanter, R.M. (1993). Men and Women of the Corporation, New York, NY: Basic Books.

Laschinger, H., Wong, C., Cummings, G., \& Grau, A. (2014). Resonant leadership and workplace empowerment: The value of positive organizational cultures in reducing workplace incivility. Nursing economics, 32, 5-15, 44, quiz 16.

Lee, A., Willis, S., \& Tian, A. (2017). Empowering leadership: A meta-analytic examination of incremental contribution, mediation, and moderation. Journal of Organizational Behavior, 39.

Liden, R.C., Wayne, S.J., \& Sparrowe, R.T. (2000). An examination of the mediating role of psychological empowerment on the relations between the job, interpersonal relationships, and work outcomes. The Journal of Applied Psychology, 85(3), 407-416.

Liu, S. (2012). The impact of forced use on customer adoption of self-service technologies. Computers in Human Behavior, 28, 1194-1201.

Liu, R., Ding, Z., Wang, Y., Jiang, X., Sun, W., Wang, D., Mou, Y., \& Liu, M. (2021). The relationship between symbolic meanings and adoption intention of electric vehicles in China: The moderating effects of consumer self-identity and face consciousness. Journal of Cleaner Production, 288,

López, G. (2007). The social representation of drugs from a group of inmates at two Mexican prisons. Anales de Psicología, 23, 85-91.

Mäkiniemi, J-P., Pirttila-Backman, A-M., \& Pieri, M. (2011). Ethical and unethical food. Social representations among Finnish, Danish and Italian students. Appetite, 56, 495-502.

Maynard, M., Gilson, L., \& Mathieu, J. (2012). Empowerment—fad or fab? A multilevel review of the past two decades of research. Journal of Management, 38, 1231-1281.

Mckenna, R., Merkel, E., Fehrenbach, D., Mehne, S., \& Fichtner, W. (2013). Energy efficiency in the German residential sector: A bottom-up building-stock-model-based analysis in the context of energy-political targets. Building and Environment, 62, 77-88.

Meuter, M., Ostrom, A., Bitner, M., \& Roundtree, R. (2003). The influence of technology anxiety on consumer use experiences with self-service technologies. Journal of Business Research, 56, 899-906.

Moliner, P., Joule, R.V., \& Flament, C. (1995). A counter-attitudinal essay and the structure of social representations. International Review of Social Psychology, 27, 44-55.

Moliner, Pascal. (1995). A two-dimensional model of social representations. European Journal of Social Psychology, 25(1), 27-40.

Moscovici, S. (1961). La psychanalyse, son image et son public. Paris: PUF.

Moscovici, S. (1988). Notes towards a description of Social Representations. European Journal of Social Psychology, 18(3), 211-250.

Mouret, M., Grégory, L., Lo Monaco, G., Urdapilleta, I., \& Parr, W. (2013). Social representations of wine and culture: A comparison between France and New Zealand. Food Quality and Preference, 30.

Mullen, B., Calogero, R., \& Leader, T. (2007). A social psychological study of ethnonyms: Cognitive representation of the in-group and intergroup hostility. Journal of personality and social psychology, 92, 612-30.

Parasuraman, A., \& Colby, C.L. (2015). An updated and streamlined technology readiness index: TRI 2.0. Journal of Service Research, 18(1), 59-74.

Pawlowski, S., Kaganer, E., \& III, J. (2007). Focusing the research agenda on burnout in IT: Social representations of burnout in the profession. European Journal of Information Systems, 16, 612-627.

Pignon, B., Tebeka, S., Leboyer, M., \& Geoffroy, P-A. (2017). De « Psychose maniaco-dépressive » à «Troubles bipolaires »: Une histoire des représentations sociales et de la stigmatisation en rapport avec la nosographie. Annales Médico-psychologiques, Revue Psychiatrique, 175(6), 514-521.

Pranić, L., \& Roehl, W. (2012). Rethinking service recovery: A customer empowerment (CE) perspective. Journal of Business Economics and Management, 13, 242-260. 
Prigge, J.-K., Dietz, B., Homburg, C., Hoyer, W.D., \& Burton, J.L. (2015). Patient empowerment: A cross-disease exploration of antecedents and consequences. International Journal of Research in Marketing, 32(4), 375-386.

Quinn, R.E., \& Spreitzer, G.M. (1997). The road to empowerment: Seven questions every leader should consider. Organizational Dynamics, 26(2), 37-49.

Rateau, P., Moliner, P., Guimelli, C., \& Abric, J.C. (2011). Social representation theory. In P.A.M. Van Lange, A.W. Kruglanski, E.T. Higgins (Eds.), Handbook of theories of social psychology (pp. 477-487). Thousand Oaks: Sage.

Reinders, M.J., Dabholkar, P.A., \& Frambach, R.T. (2008). Consequences of forcing consumers to use technology-based self-service. Journal of Service Research, 11(2), 107-123.

Rodrigues, H., Ballester, J., Saenz-Navajas, M.P., \& Valentin, D. (2015). Structural approach of social representation: Application to the concept of wine minerality in experts and consumers. Food Quality and Preference, 46, 166-172.

Saridakis, G., Lai, Y., \& Cooper, C. (2016). Exploring the relationship between HRM and firm performance: A meta-analysis of longitudinal studies. Human Resource Management Review, 27.

Sashkin, M. (1976). Changing toward participative management approaches: A model and method. Academy of Management Review, 1(3), 75-86.

Schweitzer, V., \& Simon, F. (2021). Self-construals as the locus of consumer paradoxical empowerment in self-service retail technology environments. Journal of Business Research, 126, 291-306.

Seibert, S., Wang, G., \& Courtright, S. (2011). Antecedents and consequences of psychological and team empowerment in organizations: A meta-analytic review. The Journal of applied psychology, 96, 981-1003.

Seligman, M.E., \& Beagley, G. (1975). Learned helplessness in the rat. Journal of Comparative and Physiological Psychology, 88(2), 534-541.

Shove, E., \& Walker, G. (2014). What is energy for? Social practice and energy demand. Theory, Culture \& Society, 31(5), 41-58.

Spreitzer, G.M. (1995). Psychological empowerment in the workplace: Dimensions, measurement, and validation. Academy of Management Journal, 38(5), 1442-1465.

Spreitzer, G.M., Kizilos, M.A., \& Nason, S.W. (1997). A dimensional analysis of the relationship between psychological empowerment and effectiveness satisfaction, and strain. Journal of Management, 23(5), 679-704.

Srivastava, A., Bartol, K., \& Locke, E. (2006). Empowering leadership in management teams: Effects on knowledge sharing, efficacy, and performance. Academy of Management Journal, 49, 1239-1251.

Strengers, Y. (2013). Smart energy technologies in everyday life: Smart utopia? (S.1.): Palgrave Macmillan UK.

Thomas, K.W., \& Velthouse, B.A. (1990). Cognitive elements of empowerment: An « interpretive » model of intrinsic task motivation. The Academy of Management Review, 15(4), 666-681.

Torriti, J., Hassan, M.G., \& Leach, M. (2010). Demand response experience in Europe: Policies, programs and implementation. Energy, 35, 1575-1583.

Ueno, T., Sano, F., Saeki, O., \& Tsuji, K. (2006). Effectiveness of an energy-consumption information system on energy savings in residential houses based on monitored data. Applied Energy, 83(2), 166-183.

Valdez-Tah, A., Huicochea-Gómez, L., Ortega-Canto, J., Nazar, A., \& Ramsey, J. (2015). Social Representations and Practices Towards Triatomines and Chagas Disease in Calakmul, México. Plos one, 10.

Van Dam, S., Bakker, C.A., \& Hal, J. (2010). Home energy monitors: Impact over the medium-term. Building Research \& Information, 38, 458-469.

Venkatesh, V., \& Bala, H. (2008). Technology acceptance model 3 and a research agenda on interventions. Decision Sciences, 39(2), 273-315. 
Venkatesh, V., Thong, J., \& Xu, X. (2012). Consumer acceptance and use of information technology: Extending the Unified Theory of Acceptance and Use of Technology. MIS Quarterly, 36, 157-178.

Verges, P. (1992). The evocation of money: A method for defining the central core of a representation. Psychological Bulletin, 45(405), 203-209.

Wallenborn, G., Orsini, M., \& Vanhaverbeke, J. (2011). Household appropriation of electricity monitors. International Journal of Consumer Studies, 35, 146-152.

Whitmore, A., Agarwal, A. \& Da Xu, L. (2015) The Internet of Things-A survey of topics and trends. Information System Frontiers, 17, 261-274.

Wilson, C., Hargreaves, T., \& Hauxwell-Baldwin, R. (2017). Benefits and risks of smart home technologies. Energy Policy, 103, 72-83.

Winskell, K., Singleton, R., Sabben, G., Tiendrébéogo, G., Obong’o, C., Dia, F.L., Stephenson, R. (2020). Social representations of the prevention of heterosexual transmission of HIV among young Africans from five countries, 1997-2014. Plos One, 15(3).

Zbinden, A., Souchet, L., Girandola, F., \& Bourg, G. (2011). Communication engageante et représentations sociales: Une application en faveur de la protection de l'environnement et du recyclage. Pratiques Psychologiques, 17, 285-299.

Zhang, X.M., \& Bartol, K. (2010). Linking empowering leadership and employee creativity: The influence of psychological empowerment, intrinsic motivation, and creative process engagement. Academy of Management Journal, 53, 107-128.

\section{APPENDICES}

\section{APPENDIX A \\ CLASSIFICATION OF SOCIAL REPRESENTATION ELEMENTS OBTAINED FROM HIERARCHICAL ANALYSIS OF SPONTANEOUS EVOCATIONS}

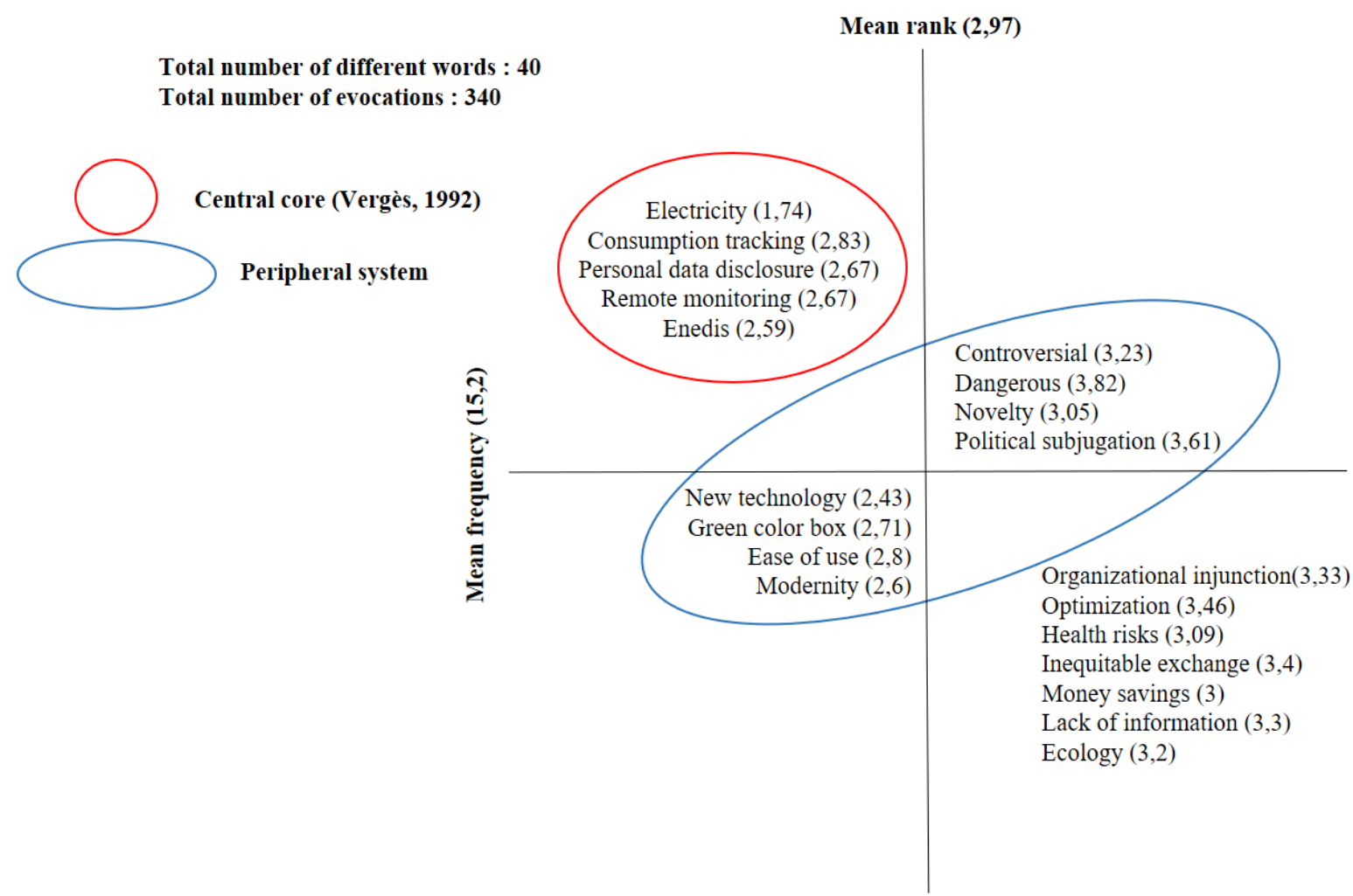

164 Journal of Organizational Psychology Vol. 21(3) 2021 


\section{APPENDIX B \\ CENTRALITY SCORES OF THE ITEMS OBTAINED FROM CONTROL OF THE CENTRAL CORE (STEP 3)}

\begin{tabular}{|l|lll|}
\hline Elements of SR (\% of responses) & $\begin{array}{l}\text { This is Linky } \\
\text { smart meter (a) }\end{array}$ & $\begin{array}{l}\text { It might be Linky } \\
\text { smart meter (b) }\end{array}$ & $\begin{array}{l}\text { This is not Linky } \\
\text { smart meter (c) }\end{array}$ \\
\hline Novelty & 87,41 & 10,00 & 2,59 \\
Remote monitoring & 81,11 & 15,19 & 3,70 \\
Consumption tracking & 77,04 & 20,37 & 2,59 \\
Controversies & 76,30 & 17,04 & 6,67 \\
Political subjugation & 75,93 & 19,63 & 4,44 \\
Modernity & 71,85 & 24,81 & 3,33 \\
Organizational injunction & 70,00 & 24,81 & 5,19 \\
Personal data disclosure & 68,52 & 22,96 & 8,52 \\
Electricity & 65,19 & 28,15 & 6,67 \\
New technology & 63,70 & 29,26 & 7,04 \\
Green color box & 63,33 & 24,81 & 11,85 \\
Ease of use & 60,37 & 33,70 & 5,93 \\
Optimization & 59,63 & 29,63 & 10,74 \\
Inequitable exchange & 51,48 & 34,81 & 13,70 \\
Enedis & 51,11 & 38,15 & 10,74 \\
Lack of information & 43,70 & 29,63 & 26,67 \\
Health risks & 36,30 & 35,93 & 27,78 \\
Ecology & 34,07 & 42,96 & 24,07 \\
Money savings & 33,33 & 43,33 & 23,33 \\
Dangerous & 27,41 & 42,22 & 30,37 \\
\hline
\end{tabular}

Elements of the central core in dark grey (positive answers frequency $>$ à $2 / 3, X^{2}$ significant at .05) 